\title{
Neutrophil-Activating Peptide 2
}

National Cancer Institute

\section{Source}

National Cancer Institute. Neutrophil-Activating Peptide 2. NCI Thesaurus. Code C26614.

Neutrophil-activating peptide 2 (70 aa, $\sim 8 \mathrm{kDa}$ ) is encoded by the human PPBP gene.

This protein plays a role in chemokine receptor activation, chemotaxis and neutrophil activation. 